[Agr. Biol. Chem., Vol. 35, No. 8, p. 1180 1187, 1971]

\title{
Phospholipases of Escherichia coli
}

\section{Part I. Lipoprotein Phospholipase A*†}

\author{
By Isao SHibuYa and Bunji MARUo \\ Institute of Applied Microbiology, University of Tokyo, \\ Bunkyo-ku, Tokyo
}

Received October 30, 1970

\begin{abstract}
Phospholipase A activity was hardly detected in Escherichia coli K 12 sonicate when solventextracted (free) ${ }^{32} \mathrm{P}$-phosphatides were used as substrate. Phosphatides bound in membrane were, however, actively hydrolyzed to give the corresponding lysolipids by an endogenous enzyme. The results indicated the presence in $E$. coli membrane of a novel phospholipase which can be more precisely called as lipoprotein phospholipase A. Lysophospholipase was shown to be present in the cellular soluble fraction.

With free phosphatides as substrate, alcohols and some water-miscible solvents, as well as nonionic detergents, markedly stimulated phospholipase $\mathrm{A}$ activity of the membrane, possibly by enabling the substrate to hold physical state in someway simillar to that in the membrane. Possible role of this enzyme in membrane lipid metabolism is discussed.
\end{abstract}

Membrane structures have been recognized to be responsible for the highly ordered, efficient and specific physiological activities of living cells, and lipids, as major and essential components of biomembranes, have also been accepting biochemists' attention. Escherichia coli, a Gram-negative bacterium, has the simplest lipid composition, thus far studied, and its major phosphatides, PE and PG are located

* Abbreviations used in this text are as follows: PLase, phospholipase; PE, phosphatidylethanolamine; PG, phosphatidylglycerol; LPE, lysophosphatidylethanolamine; LPG, lysophosphatidylglycerol; GPE, glycerylphosphorylethanolamine; GPG, glycerylphosphorylglycerol; EP, ethanolamine phosphate; GP, glycerol phosphate; $\mathrm{Pi}$, inorganic orthophosphate.

$\dagger$ The results of this paper were presented at the annual meetings of Japanese Biochemical Society ${ }^{1,2}$ ? and Agricultural Chemical Society of Japan. ${ }^{31}$

1) I. Shibuya and B. Maruo, Seikagaku, 40, 467 (1968).

2) idem, ibid., 41, 600 (1969).

3) idem, Abstracts of Papers, Annual Meeting of Agricultural Chemical Society of Japan, Fukuoka, 1970 , p. 428. in the membrane. ${ }^{4-5)}$ Together with the availability of other biochemical and genetical informations, $E$. coli seems to be most suited to. the study of the roles of individual lipids in cell physiology.

Major lipids of $E$. coli turn over actively. Not only PG as described by many workers, ${ }^{4,7 \sim 91}$ but also PE is being degraded with the same half life, when studied with non-synchronized cell populations. ${ }^{101}$ The role of the lipid turnover, if any, is not understood at present. Enzymes responsible for these phenomena have

4) I. Shibuya, H. Honda and B. Maruo, Abstracts. of Papers, VIIth International Congress of Biochemistry, Tokyo, 1967, IV, p. 723.

5) idem, Agr. Biol. Chem., 31, 633 (1967).

6) Y. Nagata, I. Shibuya and B. Maruo, J. Biochem., 61, 623 (1967).

7) J. Kanfer and E. P. Kennedy, J. Biol. Chem., 238, 2919 (1963).

8) Y. Kanemasa, Y. Akamatsu and S. Nojima, Biochim. Biophys. Acta, 144, 382 (1967).

9) D. C. White and A. N. Tucker, J. Lipid Res,, 10, 220 (1969).

10) Turnover experiments will be reported in another paper. 
not been studied.

The present series of investigation is concerned with analysis of membrane lipid metabolism on enzyme basis and possible relations to membrane physiology of $E$. coli cells. Detection of a novel PLase A, which acts only on membrane-bound phosphatides, and remarkable enhancing effect of organic solvents on the free lipid hydrolysis are described in this paper.

\section{MATERIALS AND METHODS}

Bacterial strain and culture conditions. Escherichia coli K12 IAM 1264, originally ATCC 10798, was used throughout in this experiment. Cells were grown at $37^{\circ} \mathrm{C}$ in a nutrient broth medium with the following composition: in 1 liter, nutrient broth (Difco) $8 \mathrm{~g}$; Polypepton (Daigo) $5 \mathrm{~g}$; yeast extract (Daigo) $2 \mathrm{~g}$; sodium chloride $2 \mathrm{~g}, \mathrm{pH} 7.2$. This culture medium (NBY medium) contained $208 \mu \mathrm{g}$ total phosphorus per ml and was found to be suited to the preparation of $32 \mathrm{P}$ uniformly labeled cells.

Preparation of cell membrane fraction. One gram on dry weight basis of washed log-phase cells was incubated in $300 \mathrm{ml}$ of $50 \mathrm{~mm}$ Tris- $\mathrm{HCl}$ buffer, $\mathrm{pH} 8.0$, containing $120 \mathrm{mg}$ disodium ethylenediaminetetraacetate, $60 \mathrm{mg}$ lysozyme and $5 \mathrm{mg}$ pancreatic ribonuclease at $30^{\circ} \mathrm{C}$ for $15 \mathrm{~min}$. To this mixture, $130 \mathrm{mg} \mathrm{MgCl}_{2-}$ $6 \mathrm{H}_{2} \mathrm{O}$ and $3 \mathrm{mg}$ deoxyribonuclease were added and cooled to $0^{\circ} \mathrm{C}$. Refregerated centrifugation of this mixture at $13,000 \mathrm{rpm}$ for $20 \mathrm{~min}$ gave crude membrane fraction as pellet which was then resuspended by - Teflon homogenizer in $40 \mathrm{ml}$ of $50 \mathrm{~mm}$ Tris- $\mathrm{HCl}$, pH 7.6, and centrifuged at $3000 \mathrm{rpm}$ for $10 \mathrm{~min}$. The supernatant was centrifuged at $13,000 \mathrm{rpm}$ for $20 \mathrm{~min}$. The pellet was resuspended in $20 \mathrm{ml}$ of water and sonicated at $9 \mathrm{kc}$ for $5 \mathrm{~min}$. Final suspension, membrane preparation, was stored in a freezer until used.

${ }^{32} \mathrm{P}$ labeled membrane fraction was prepared in an identical manner with a reduced scale from ${ }^{32} \mathrm{P}$ uniformly labeled cells.

Preparation of ${ }^{22} P$-phosphatides. E. coli cells from stock agar slunt was inoculated into $100 \mathrm{ml} \mathrm{NBY}$ medium which contained $2.5 \mathrm{mCi}$ 32P-orthophosphate (final specific activity, $0.12 \mathrm{mCi} / \mathrm{mg}$ total $\mathrm{P}$ ), and grown at $37^{\circ} \mathrm{C}$ until the population reached to early station- ary phase. Phosphatide content in this phase was about twice of mid-log cells. Labeled cells were harvested by centrifugation, washed with $10 \mathrm{~mm}$ Tris- $\mathrm{HCl}, \mathrm{pH}$ 7.7 twice. The cell pellet was resuspended in $10 \mathrm{ml}$ of methanol and warmed at $55^{\circ} \mathrm{C}$ for $15 \mathrm{~min}$. Twenty $\mathrm{ml}$ of chloroform was added to the methanol suspension which was then allowed to stand overnight at room temperature. The cell suspension was filtered through a filter paper and the filtrate was concentrated by nitrogen gas stream. The lipid extract thus obtained was loaded as a large spot onto a triangle-shaped Whatman $3 \mathrm{MM}$ paper. The dried paper was first eluted with water to eliminate water-soluble contaminants, then dried and eluted with chloroform-methanol $(2: 1)$. The purified ${ }^{32} \mathrm{P}-\mathrm{lipids}$ in this eluate was kept in a freezer. A typical composition of this ${ }^{32} \mathrm{P}$-lipid preparation was, in ${ }^{32} \mathrm{P}$ per cent, $\mathrm{PE} \mathrm{76.1,} \mathrm{PG} \mathrm{22.6,}$ cardiolipin 1.5, and usually no water-soluble contaminant nor lysolipid was detected.

Assay of PLase activity. When extracted phosphatides were used as substrate, ${ }^{32} \mathrm{P}$-lipid mixture, without separation of components, in chloroform-methanol was placed in 3 ml-test tubes (diameter $7 \mathrm{~mm}$ ) and dried by evaporation. Five to $10 \mu l$ of enzyme suspension, cell sonicate or fractions therefrom, was added with additions as specified, vigorously agitated and incubated at $37^{\circ} \mathrm{C}$ with constant shaking. When membranebound lipids were to be studied as substrate, ${ }^{32} \mathrm{P}$ membrane suspension with or without unlabeled cell fractions was placed in test tubes and incubated in the same way. After the desired period of reaction, test tubes were cooled to $0^{\circ} \mathrm{C}$ and one-tenth volume of $55 \%$ trichloroacetic acid was added,

For phosphatide analysis, the PLase reaction mixtures were applied onto a commercially available Silicagel Paper (Carl Schleicher and Schull, No. 289) or anionic ion-exchange resin paper (Amberlite WB-2, Rohm and Haas) without previous extraction. ${ }^{11}$ Descending development with diisobutylketone-acetic acidwater $(8: 5: 1)$ was carried out at room temperature. Chromatogram strips were examined either by autoradiography followed by direct radioactivity measurement with a wide-area GM tube (Nihon Musen, Model 5006) or by a radiochromatogram scanner with a chart integrator (Packard Model 7201). Quantitative estimate of each lipid was simply made from ${ }^{32} \mathrm{P}$ radioactivity. Identification of phosphatides was carried

11) I. Shibuya and B. Maruo, Agr. Biol. Chem., 30, 1058 (1966). 
out by established procedures. $5,6,12$ )

Water-soluble ${ }^{32} \mathrm{P}$-compounds produced by PLase reactions were analyzed by descending chromatography of the reaction mixtures on Whatman $3 \mathrm{MM}$ with phenol-water $(100: 40 \mathrm{w} / \mathrm{w})$. 32P-GPE, -GPG, -EP, -GP and $-P_{1}$ were well separated by this one-dimensional chromatography.

Miscellaneous. Phosphatide phosphorus was determined by the periodate method.131 Total phosphorus content was assayed by the method of Fiske and Subbarow ${ }^{141}$ modified to meet the micro scale experiments. Protein was determined by the procedure of Lowry et al. 15) $^{2}$

Snake (Crotalus terr. terr.) venom PLass A was purchased from Boehringer, Mannheim, PLase C of Clostridium welchii from Mann Research Laboratories, New York. in $E$. coli cells using solvent-extracted ${ }^{32} \mathrm{P}$ phosphatide mixture as substrate. The cells were sonicated at $9 \mathrm{kc}$ in $50 \mathrm{~mm}$ Tris- $\mathrm{HCl}, \mathrm{pH}$ 7.7 , and the sonicate was used as the enzyme source without fractionation. As far as the free ${ }^{32} \mathrm{P}$-phosphatides were used, very low PLase A activity, if not at all, was detected by chromatographic analysis of reaction mixtures, regardless of the bacterial cell age, $\mathrm{pH}$ of the reaction mixture and reaction temperature, under which condition commercial venom PLase A and Clostridium PLase C expressed satisfactory activities. Sonication of ${ }^{32} \mathrm{P}$-lipids at $20 \mathrm{kc}$ for $1 \mathrm{hr}$ and the addition of ether or calcium ions did not enhance the PLase A activity.

Table I. Hydrolysis of Membrane-bound Phosphatides by Endogenous PLases. Ghanges in Lipjd Pattern

${ }^{32} \mathrm{P}$-uniformly labeled $E$. coli membrane fraction which contained $23 \mathrm{~m} \mu$ moles bound phosphatides in $20 \mu 110 \mathrm{~mm}$ Tris- $\mathrm{HCl}, \mathrm{pH} 7.7$ was incubated at $37^{\circ} \mathrm{C}$ for $2 \mathrm{hr}$. The first line shows the composition of the membrane before the incubation. Where indicated, sonicate of $77 \mu \mathrm{g}$ log-phase cells or its $13,000 \mathrm{rpm}$ supernatant or particulate fraction was included in reaction mixtures.

\begin{tabular}{llrrrrr}
\hline \multirow{2}{*}{ Addition } & & \multicolumn{4}{c}{ Percentage 32 P radioactivity } & \multirow{2}{*}{ L } \\
& & PE & PG & LPE & LPG & Non-lipid \\
\hline \multirow{2}{*}{ None } & Zero time & 28.0 & 8.3 & 2.9 & 0.6 & 60.0 \\
& & 8.6 & 4.2 & 20.2 & 3.1 & 62.2 \\
\hline \multirow{3}{*}{ Sonicated } & whole cells & 4.6 & 4.3 & 14.3 & 1.7 & 73.6 \\
& supernatant & 5.2 & 8.5 & 9.3 & 0.9 & 75.2 \\
& particulate & 5.3 & 4.5 & 23.8 & 2.8 & 62.6 \\
\hline
\end{tabular}

\section{RESULTS}

PLase $A$ activity with extracted lipids as substrate

As the first step of the present investigation, efforts were made to detect PLase $\mathrm{A}$ activity

12) M. Kates, "Lipid Chromatographic Analysis," Vol. I, ed. by G. V. Marinetti, Marcel Dekker, Inc., New York, N. Y., 1967, p. 1.

13) I. Shibuya, H. Honda and B. Maruo, Agr. Biol. Chem., 31, 111 (1967).

I4) C. H. Fiske and Y. Subbarow, J. Biol. Chem., 66, 375 (1925).

15) O. H. Lowry, N. J. Rosebrogh, A. L. Farr and R. J. Randall, ibid., 193, 265 (1951).

\section{Hydrolysis of membrane-bound phosphatides}

Membrane fraction from ${ }^{32} \mathrm{P}$-uniformly labeled cells of log-phase was prepared, sonicated and suspended in $10 \mathrm{~mm}$ Tris- $\mathrm{HCl}, \mathrm{pH} 7.7$. Incubation of this preparation at $37^{\circ} \mathrm{C}$ caused breakdown of endogenous ${ }^{32} \mathrm{P}-\mathrm{PE}$ and $-\mathrm{PG}$, with the concomitant formation of LPE and LPG as shown in Table I. Since isolated phosphatides are completely stable under these incubation conditions, detected changes in phosphatides must be attributed to an enzyme. The results presented in Tables I and II indicated that PLase A was the major hydrolytic 
Table II. Hydrolysis of Membrane-bound Phosphatides by Endogenous Enzymes. Changes in Water-Soluble Compounds

Reaction conditions were same as those of Table I.

\begin{tabular}{llcccccc}
\multirow{2}{*}{ Addition } & & \multicolumn{3}{c}{ 32P per cent found in the position of } \\
& & GPE & GPG & EP & GP & Pi & Lipids \\
\hline \multirow{2}{*}{ None } & Zero time & 0.3 & 0.2 & 0.6 & 0.7 & 3.4 & 40.0 \\
& & 6.2 & 1.5 & 1.6 & 1.5 & 3.3 & 34.4 \\
\hline \multirow{3}{*}{ Sonicated } & whole cells & 0.6 & 2.0 & 1.9 & 0.5 & 21.2 & 26.5 \\
& supernatant & 0.4 & 2.5 & 5.3 & 2.7 & 18.7 & 20.0 \\
& particulate & 2.6 & 2.0 & 3.4 & 3.0 & 9.4 & 35.5 \\
\hline
\end{tabular}

enzyme, although a small amount of lysophospholipase (or PLase B) seemed to be present since GPE and GPG also increased.

When non-labeled cell sonicate was added, the reaction was enhanced and lysolipids were further hydrolyzed to GPE and GPG and finally to $P_{i}$. Lysophospholipase and enzymes responsible for further degradation seemed to be present in the supernatant fraction. These re-

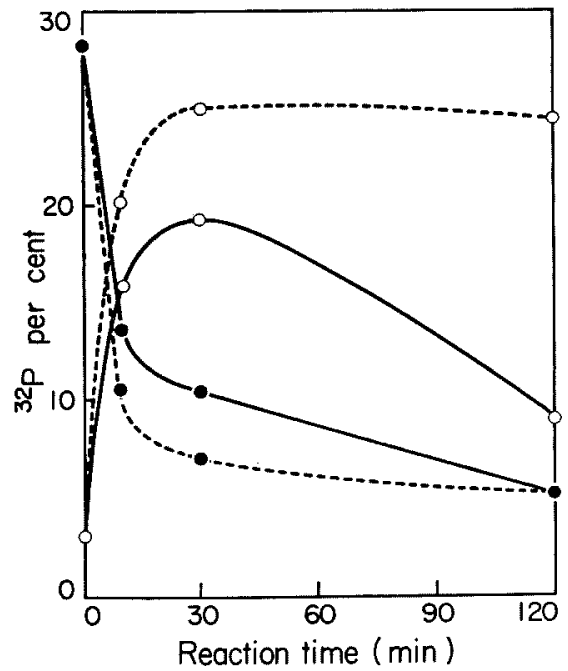

FIG. 1. Hydrolysis of Membrane-bound ${ }^{32} \mathrm{P}-\mathrm{PE}$.

Values indicate percentage ${ }^{32} \mathrm{P}$ radioactivity in the membrane. Incubation conditions were same as those of Table I. Hydrolysis of PG followed a similar Process. O: LPE, Q: PE, - : addition of 13,000 rpm supernatant, -.-: addition of $13,000 \mathrm{rpm}$ pellet. lationships were more clearly seen by a time course experiment shown in Fig. 1.

Membrane-bound phosphatides were also actively hydrolyzed by exogenous venom PLase A and Clostridium PLase C.

\section{Effect of physical state of substrate phosphatides on the susceptibility to PLase $A$}

With the purpose of understanding the reaction mechanisms as well as of obtaining an assay system useful in further characterization and purification of $E$. coli PLase A, a search was made to find out conditions under which solvent-extracted phosphatides could be hydrolyzed by the enzyme. Figure 2 shows the results. Sonicate pellet of log-phase cells most actively hydrolyzed ${ }^{32} \mathrm{P}-\mathrm{PE}$ and $-\mathrm{PG}$ when a reaction mixture contained $50 \%$ ethanol. The reaction proceeded linearly up to $80 \%$ hydrolysis or $3 \mathrm{hr}$ without producing detectable amount of water-soluble compounds, then gradually the rate decreased. Only a few per cent activity of this maximum was found when ${ }^{32}$ P-lipids were simply placed on the inner wall of the reaction tubes. Previous adsorption of the substrate on fine sea sand ${ }^{16)}$ did not result in additional susceptibility, but the adsorption to bovine serum albumin crystals and fine powder of polystyrene and polyethylene gave en-

16) H. Okuyama and S. Nojima, Biochem. Biophys. Acta, 176, 120 (1969). 


\begin{tabular}{|c|c|c|c|c|c|c|}
\hline & ADDITION & 0 & 40 & 60 & 80 & 100 \\
\hline & NONE & 更 & & & & \\
\hline س흐 & SEA SAND & 网 & & & & \\
\hline 象耑 & ALBUMIN & 㳔 & & & & \\
\hline 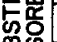 & POLYSTYRENE & & & & & \\
\hline के & POLYETHYLENE & (2) & & & & \\
\hline TR & ITON XI00 $0.5 \%$ & & & & & \\
\hline TRI & TON \& ETHANOL & & & & & \\
\hline & THANOL $50 \%$ & & & & & \\
\hline
\end{tabular}

FIG. 2. Relative PLase A Activity on Solvent-extracted 32P-Lipids.

Sonicate pellet of log-phase cells (50 $\mu$ g protein) was incubated with 0.1 $\mu$ mole phosphatides in $20 \mu \mathrm{l}$ reaction mixtures at $37^{\circ} \mathrm{C}$ for $2 \mathrm{hr}$. Where indicated, phosphatides were previously adsorbed on fine powders. Values indicate relative PLase A activity by taking the combined amounts of LPE and LPG produced with $50 \%$ ethanol as 100 .

hanced hydrolysis. Triton X100 and the combination of Triton and ethanol resulted in high activity. Another nonionic detergent, Nonidet P-40 had a simillar effect.

\section{Effect of ethanol on PLase $A$ reaction}

A survey for effectors on PLase A activity using extracted lipids as substrate revealed a remarkable enhancing effect of $50 \%$ ethanol (Fig. 2). Effect of ethanol and related organic solvents were further examined. Figure 3 shows the relationship between the ethanol concentration in reaction mixtures and PLase $\mathrm{A}$ activity of $E$. coli membrane, as well as of snake venom PLase $A$. The enzymes from both sources were most active with the alcohol of $50 \sim 60 \%$ concentration. Here again, E. coli enzyme was practically inactive without alcohol, while venom PLase A well acted on free phosphatides without ethanol.

Table III demonstrates the activation effects of various organic solvents which are miscible with water. Solvents other than alcohols, such as dioxane and acetone, were also effective. The ratio of the methylene groups to oxygen in solvent molecules seems to be critical in their effects, and when solvents were added at 50\% concentration, $2: 1$ ratio resulted in highest substrate susceptibility.

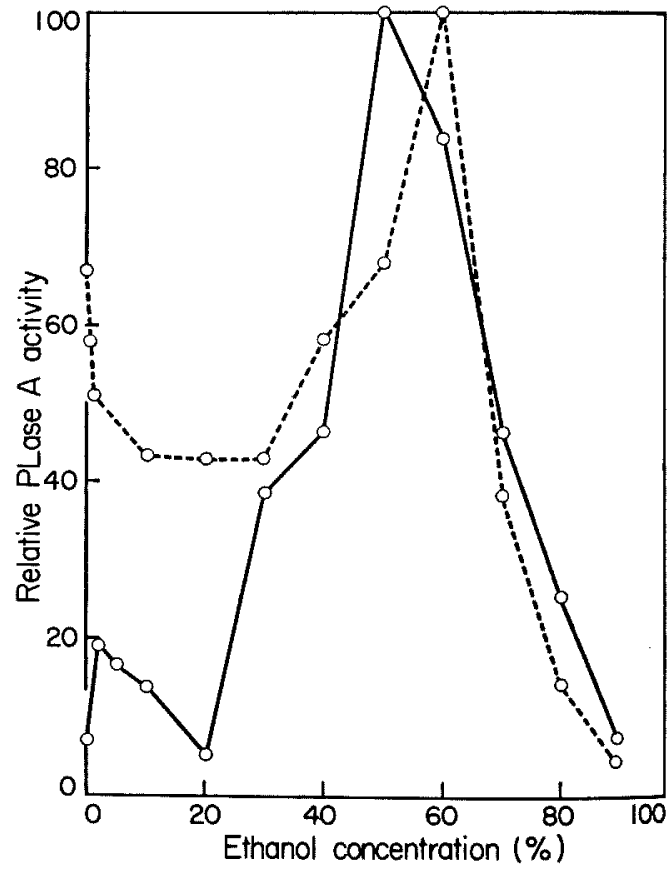

FIG. 3. Effect of Ethanol Concentration on PLase A's of $E$. coli and Snake Venom.

Reaction conditions were the same as those in Fig. 2 , except that $20 \mu l$ reaction mixture contained various concentrations of ethanol. --: E. coli PLase A; ...: snake (Crotalus terr. terr.) venom PLase A. 
TABLE III. EFFECT OF ORganIC SOLVENTS ON PLASE A ACTIVITY

\begin{tabular}{lcc}
\hline Solvent & $\%$ in water & $\begin{array}{c}\text { Relative PLase A } \\
\text { activity }\end{array}$ \\
\hline Water & - & 9 \\
Methanol & 50 & 29 \\
& 25 & 25 \\
Ethanol & 50 & 100 \\
& 75 & 25 \\
n-Propanol & 50 & 12 \\
Isopropanol & 50 & 65 \\
Ethyl cellosolve & 50 & 108 \\
Dioxane & 50 & 91 \\
Acetone & 50 & 59 \\
\hline
\end{tabular}

Extracted 32P-phosphatides $(0.1 \mu$ mole) were incubated with sonicate pellet from log-phase cells (50 $\mu$ g protein) at $37^{\circ} \mathrm{C}$ for $2 \mathrm{hr}$ in $20 \mu \mathrm{l} 10 \mathrm{~mm}$ Tris$\mathrm{HCl}$, pH 7.7 containing one of the above organic solvents. Relative amounts of LPE plus LPG produced are shown by taking that with $50 \%$ ethanol as 100 .

Table IV. Relative Plase A Activity WITH VARIOUS EFFECTORS

\begin{tabular}{lcc} 
Addition & $\begin{array}{c}\text { Final } \\
\text { concentra- } \\
\text { tion }\end{array}$ & $\begin{array}{c}\text { Relative } \\
\text { hydrolysis } \\
\text { rate }\end{array}$ \\
\hline None & - & 100 \\
$\begin{array}{l}\text { Cetyltrimethylammonium } \\
\text { chloride }\end{array}$ & $0.250^{\circ}$ & 0 \\
Glucose & $0.25 \mathrm{mM}$ & 116 \\
Ascorbate & $2.5 \mathrm{mM}$ & 123 \\
Ferric chloride & $2.5 \mathrm{mM}$ & 148 \\
Calcium chloride & $2.5 \mathrm{mM}$ & 388 \\
$\begin{array}{l}\text { Magnesium chloride } \\
\text { None, preheated at } 100^{\circ} \mathrm{C},\end{array}$ & $2.5 \mathrm{mM}$ & 190 \\
$\quad 15 \mathrm{~min}$ & - & 280 \\
None, preincubated at & - & 100 \\
$37^{\circ} \mathrm{C}, 24 \mathrm{hr}$ & - & \\
\hline
\end{tabular}

Extracted $32 \mathrm{P}$-phosphatides $(0.2 \mu$ moles $)$ were incubated at $37^{\circ} \mathrm{C}$ for $2 \mathrm{hr}$ with cell sonicate pellet ( $100 \mu \mathrm{g}$ protein) with $50 \%$ ethanol and the above additions.

\section{Properties of PLase $A$ in membrane}

Taking the activity with $50 \%$ ethanol as 100 , relative hydrolysis rates on free phosphatides with possible effectors are listed in Table IV. $\mathrm{Ca}^{2+}$ ions strongly activated the reaction. $\mathrm{Mg}^{2+}$ ions gave almost a half activation of $\mathrm{Ca}^{2+}$ at the same concentration. A cationic detergent, cetyltrimethylammonium chloride completely inhibited the activity under the present incubation conditions. Glucose, ${ }^{171}$ ascorbate and ferric ions, ${ }^{18)}$ reported with PLase A's of other bacteria to be specific reaction regulators, did not show marked effects on the $E$. coli enzyme. This PLase A activity in membrane fraction was found extremely stable. Heating in a boiling water bath for $15 \mathrm{~min}$ rather resulted in three-fold increase in activity. Incubation of the membrane fraction at $37^{\circ} \mathrm{C}$ for $24 \mathrm{hr}$ did not alter the enzyme activity.

\section{DISCUSSION}

While PE and PG bound in the membrane of $E$. coli were actively hydrolyzed to give LPE and LPG, respectively, and therefore PLase A must be present in the membrane fraction of this bacterium, solvent-extracted ${ }^{32} \mathrm{P}$-phosphatides were practically not susceptible to the sonicate of $E$. coli cells. Snake venom PLase A and Clostridium PLase $\mathrm{C}$ easily acted on the extracted lipids under identical incubation conditions. These discrepancies strongly suggested that PLase A of E. coli K 12 was a unique enzyme in its substrate specificity, not in chemical but in physical means. It is, therefore, not unreasonable to call this newtype PLase as "lipoprotein phospholipase A". All other phospholipases, thus far reported, ${ }^{19}$ act on free phosphatides and most of them are known to be excreted from cells to hydro-

17) T. Yamaguchi and M. Morishita, Abstracts of Papers, Annual Meeting of Agricultural Chemical Society of Japan, Tokyo, 1969, p. 262.

18) Y. Ono and S. Nojima, Biochim. Biophys. Acta, 176, 111 (1969).

19) Review articles: M. Matsumoto, K. Tamiya, S. Suzuki and M. Miwa, Tampakushitsu, Kakusan, Koso (Protein, Nucleic Acid, Enzyme, Kyoritsu Shuppan, Tokyo, in Japanese), 14, 643; 811; 906 (1969). 
lyze extracellular lipid materials. Observed substrate specificity of $E$. coli PLase A, as described in this paper, would be quite reasonable if it would be responsible for the turnover of membrane-bound lipids. It may be interesting to examine whether intracellular PLase A's of other bacteria and higher organisms are of this type, lipoprotein phospholipases.

Since the membrane preparations contained both the bound phosphatides and the enzyme, it was difficult to further characterize this PLase A without separation from each other. We have not succeeded in preparing enzymefree membrane, because of the extreme stability of this enzyme and the integration of the enzyme in membrane architecture. Attempts were therefore made to find out an artificial condition under which free (solvent-extracted) phosphatides were hydrolyzed by $E$. coli PLase A. A remarkable enhancing effects of ethanol and other water-miscible solvents, as described here, have not been reported yet for any PLase A's. ${ }^{19 !}$ There may be at least four possible explanations for their effect: i) solubilization or dispersion of substrate phosphatides to yield increased chance of contacts with the enzyme; ii) activation of enzyme molecules or inactivation of an endogenous inhibitor as found in snake venom; ${ }^{201}$ iii) occurrence of enzymecatalyzed alcoholysis rather than hydrolysis; and iv) change in physical conformation of phosphatides to give the susceptible form to the enzyme. Possibility i) is not likely since phosphatides (75\% PE, 25\% PG) were absolutely insoluble in $50 \%$ ethanol and aggregate. Micelles or liposomes were much more difficult to be formed than in pure water. Possibility ii) is also not reasonable as the enzyme molecules in the identical state actively attacked the membrane-bound lipids without solvents, and the addition of ethanol to the endogenous substrate system caused no further activation. The possibility of alcoholysis is very unlikely,

20) B. M. Braganca, Y. M. Sambray and R. Y. Sambray, European J. Biochem., 13, 410 (1970). since non-alcoholic solvents, such as dioxane and acetone were also effective, and the free fatty acids were the major enzymatic products. Kinetic experiments, to be described in a subsequent paper in detail, suggested that $50 \%$ ethanol stimulated the binding of free phosphatides with membrane protein, thus forming the susceptible substrate. Nonionic detergents such as Triton X100 form mixed micelles with phosphatides which might be simillar in some extent to the native lipoprotein as far as the lipid conformation and the surface nature are concerned. Non-additional effects of alcohol and Triton (Fig. 2) would support the different mechanisms. The hydrolysis stimulation by previous adsorption of phosphatides on hydrophobic materials would also have resulted in the orientation of hydrophilic regions of the lipids.

Except for the cellular localization and substrate specificity in terms of physical state, $E$. coli PLase A was found to be simillar to the well studied venom enzymes. ${ }^{19,211}$ Both require divalent cations for their maximum activity and are extremely heat-stable. In addition, a significant activation was observed when $E$. coli enzyme was heated, suggesting the presence of a regulation mechanism. Glucose and $\mathrm{FeCl}_{\mathrm{g}}$ ascorbate, reported to regulate the Bacillus megaterium PLase $\mathrm{A}^{17)}$ and Mycobacterium phlei PLase $A,{ }^{18}$ respectively, did not show marked effect in our present system. This means that the regulation mechanisms suggested by those authors are not universal phenomena.

As to the PLase A of E. coli, we are aware of three papers up to the present. The first paper by Proulx and Van Deenen ${ }^{221}$ described the failure of the detection of PLase A activity with extracted phosphatides. This is in accord with our finding that $E$. coli PLase A hardly hydrolyzes free phosphatides unless alcohols or detergents are added to the reaction system.

21) M. A. Wells and D. J. Hanahan, Biochemistry, 8, 414 (1969).

22) P. R. Proulx and L. L. M. Van Deenen, Biochim. Biophys. Acta, 114, 171 (1967). 
After our first report of the presence of lipoprotein phospholipase $\mathrm{A},{ }^{11}$ two papers describing the detection of PLase A in E. coli cells appeared. Okuyama and Nojima ${ }^{16)}$ assayed PLase A with labeled phosphatides previously adsorbed on sea sands. Their substrate had high specific radioactivity and the enzyme activity detected was much lower (Nojima, personal communication) when compared to the activity with alcohol. Fung and Proul $x^{231}$ recently reported the presence of PLase A of very low activity and the enhanced hydrolysis of phosphatides when deoxycholate was add-

23) C. K. Fung and P. Proulx, Canadian J. Biochem., 47,371 (1969). ed. All these reports do not conflict with our present results.

In this paper, we are not able to describe the PLase A activity quantitatively, not only because of the crudity of the present enzyme system, but also of the lack of adequate methodology to express an enzyme activity when lipids are involved in the reaction. Seeking of a method which can deal with micelle and/ or membrane lipids quantitatively is now highly desirable.

Isolation of PLase A from the membrane, characterization of its substrate specificity and the examination of possible roles in membrane physiology are in progress and will be reported later. 